\title{
The Influence of Information Acceptance on Information Use Performance in the Case of Vulnerable Classes
}

\author{
Soonduck Yoo ${ }^{1} \&$ Jong-Sun Park ${ }^{2}$ \\ ${ }^{1}$ International business department, Hansei University, South Korea \\ ${ }^{2}$ Professional Graduate School Ph. D program, Seoul National University of Science \& Technology, Seoul, South \\ Korea \\ Correspondence: Jong-Sun Park, Professional Graduate School Ph. D program, Seoul National University of Science \\ \& Technology, Seoul, South Korea.
}

Received: April 30, 2019

doi:10.5430/ijfr.v10n5p474
Accepted: May 30, 2019

Online Published: June 11, 2019

URL: https://doi.org/10.5430/ijfr.v10n5p474

\begin{abstract}
This study analyzed the effect of information acceptance on the information use performance for the vulnerable groups. The sample group was classified into general public group and vulnerable groups residing in Korea, and the vulnerable groups were divided into the disabled, the low - income group, the elderly group and the farmers. The characteristics of the vulnerable groups were selected by the competence level, use motive, and use attitudes and the correlation between each factor and use utilization was analyzed. In all groups, the use motive and the use attitude showed a strong positive correlation with the use performance of .682. In particular, the information use attitude and the information use performance were closely related. The correlation between the use attitude and use performance of the vulnerable groups were investigated in the order of lower grade (.695), farmers \& fishermen (.688), elderly (.674), and disabled (.672). In conclusion, this study shows that if use attitude is high, use performance is high. Therefore, in order to expand the acceptance of information on vulnerable groups, various programs that can increase the use attitude of information should be introduced. Through this, it was found that the vulnera-ble groups could induce the use attitude of information and the satisfaction of the use performance, and ultimately the digital information divide could be reduced by improving the information acceptance of the vulnerable groups. This study has limitations in securing various contents of inquiry based on questionnaire survey. It is necessary to analyze various factors besides factors selected as environmental fac-tors of information acceptance as characteristics of vulnerable groups.
\end{abstract}

Kewords: information acceptance, performance, vulnerable classes

\section{Introduction}

As industry and society become de-industrialized, information and knowledge have emerged as an important social component to re-place existing capital and commodities. Due to the nature of information and knowledge, it can lead to a social problem due to the information divide, undergoing a process of merchandising in the capitalist system. Unlike conventional products (such as clothes, shoes, food, etc.), information and knowledge are rapidly circulating through creation, utilization, and extinction. In addition, information and knowledge are influencing the occurrence of social inequalities (hierarchy, in-come level, sex, educational background, residence area, etc.) due to qualitative as well as quantitative changes.

With the development of informatization, there are groups that are vulnerable to information in our society, and a plan to embrace them is emerging as a national concern. The importance of a digital engagement strategy, which everyone enjoys together so that no one is left out of the benefits of the In-formation Society Technology (ICT) development, is emphasized. Because of the characteristics of information and knowledge, it can deepen global inequality and make society more polarized. Therefore, the government needs to study the ways of ensuring the accessibility of information without discrimination among the vulnerable groups and expanding the digital utilization of these groups.

The purpose of this study is to contribute to the establishment of a plan for expanding the information acceptance of the theses (vulnerable) groups through analyzing factors related to the in-formation acceptance capacity of the 
vulnerable groups. For this purpose, the factors that were used for technology acceptance model(tam) and related researchers' information were selected appropriately for this study.

\section{Literature Review}

\subsection{Digital Information Divide}

Digital information divide is the difference in access and use of information due to differences in education, income level, sex, and region (ex, urban-rural areas). As a result, it is a phenomenon that not only economic but also social imbalance occurs among the related groups. The difference in the proportion of internet users according to residence area or age, or the phenomenon of falling down of information acquisition devices such as high-speed internet in rural areas or mountainous areas are typical examples of digital information divide. The digital information divide is mainly linked to the inequality of economic, regional, physical or social opportunities and creates its influence.

As a result, the elderly who are neglected in the information do not receive the benefits of the progress of informatization but rather cannot adapt to the informationization of social services such as administration and welfare, resulting in the limitation of basic daily life and social participation opportunities. The digital information dive first occurred mainly due to the economic reasons and the difference in the initial cost for using the internet or PC, but recently there has been a gap between the users of the information according to the degree of utilization of information (Gabriel, 2017).

The recent theoretical discussion on the digital information divide distinguishes the digital information divide in three stages. The first stage is the access divide, and the second one is the gap in skill or competence level and use performance. Step 3 is the gap in outcome. In this regard, this study analyses various factors related to the use of digital devices, and aims to contribute to establishing effective support measures to resolve the digital divide in the governmental side through the study of accepting digital information on vulnerable groups.

\subsection{Technology Acceptance Model (TAM)}

The Technology Acceptance Model (TAM) was first mentioned by Davis (1989) and started with predicting perceived usefulness and perceived ease of use to predict individual acceptance of information technology. Since then, many researchers have cited this to study the capacity of other technologies (Sangakala, Ahmed \& Pahi, 2016; Cases, 2010). The technology acceptance model is still validated by many researchers for analysing various models.

Davis et al. (1989); Handa (2018) raised the question that there are likely to be variables that can affect two other determinants, perceived useful-ness and perceived ease of use. There are a number of studies that have applied additional variables other than perceived usefulness and perceived ease in the name of extended technology acceptance model.

Many researchers have modified the technology acceptance model to change the structure of the technology acceptance model itself or to add external variables in order to improve the explanatory power. In the technology acceptance model, the study was conducted using the intention to use, which is related to the attitude of use. This study was conducted by selecting a combination of major factors suggested by various researchers in accordance with the re-search purpose.

\subsection{Previous Research}

The results of the discussion on "Internet use and information gap access, utilization, and participation" at Minyoung (2011); Faisal, Tursoy \& Resatoglu (2017) study showed that the information divide phenomenon within the internet users depend on the information access, literacy and participation. The results of the analysis are as follows; First, the physical and environmental accessibility of internet users is high regardless of the class, but there is still a gap between education and income.

Second, the areas where the gap structure was most apparent were related to the capacity and level of internet use. Especially, the utilization level of the older age group was very limited.

Third, the participation sector measured the degree of involvement in information production and social interaction through internet. But it remains at a very low level as a whole, so it is important to revitalize this participatory practice.

In the study of the influence of mobile advertising characteristics on attitudes and intentions and the role of involvement, Jang, Hyung Woo (2011) analyzed the attitude and usage intention of mobile ad by combining information technology acceptance model with web advertisement model in mobile side. Measuring mobile value in this study, informality has more influence on utilization attitude than entertainment (Ali \& Haseeb, 2019). 
The results showed that mobile advertising was very focused on information. This result suggests that content providing information to mobile advertising practitioners is very important. As a result of analyzing the acceptance influence of big data technology, the intention to use, that is, to continuously use specific technology means high loyalty to technology. This has a very important impact on the decision-making process that embraces innovation and claims to be based on the proliferation of future innovations (Kim Jung Sun, 2015; Ibrahim, et.al 2018; Dincer \& Kilinç 2018).

\section{Research Model and Design}

\subsection{Research Model and Hypothesis}

It is important for individual efforts to acquire the information necessary for real life, such as technology, but ultimately, the government should create an environment to resolve the digital information divide matter. This study aims to contribute to the formation of a virtuous circle structure that can reflect the results of research on information acceptance of various groups in policy formulation in order to find the most efficient solution. Therefore, in order to analyses the information acceptance phenomenon, this study classifies the sample group into general people and vulnerable groups for information acceptance, and the characteristics of each group are extracted and surveyed. Based on the previous studies on technology and information acceptance, the following terms were used as the characteristics of the vulnerable class: the level of competence, the motive of use, the use attitude and the utilization performance.

Competency provides a useful way of explaining why I am a good person to do the job with the patterns of behavior that are common to the people who work best in the job. Thus, the level of competence in this study is to assess the ability to perform any device or task (Jermsittiparsert, 2016; Essien, et.al 2016).

In this study, the motivation for use refers to an instrument that causes a behavior using a digital device, and it is also related to a general purpose of use. According to rational behavior theory, intention to use is one of the direct determinants of behavior (Norman \& Smith 1995; Myeni \& Mvuyana 2018).

The motivation for use is to emphasize the user's activity in the digital media environment based on the activeness of the user's control (Lee, Soo-young and Hye-jung, 2006; Etale, Bingilar \& Ifurueze 2016). Motivation for use is a very important factor (Morris \& Ogan, 1996; Ferguson \& Perse, 2001; Tyagi \& Siddiqui 2017).

Attitudes are behaviors and emotions that emerge according to human values. So attitude is a habit. In this study, the attitude of using was not before the acquisition of information, and it refers to the emotional stimulation felt after learning information. Therefore, it refers to a consistent learning tendency with favorable or unfriendly feeling or emotional response to an action.

This study was selected based on the usage attitudes used in the research of Davis (1989) and Adams \& Todd (1992). Use performance refers to the results obtained after performing certain tasks and includes satisfaction with the behavior of the user. Here, the use performance is the result of using digital devices and means the result obtained or accomplished after doing something.

Table 1. Meaning of information acceptance factor

\begin{tabular}{|c|c|c|}
\hline Division & Contents & Previous research \\
\hline Use motive & The degree of ability to use computers and mobile devices & $\begin{array}{l}\text { Jeongil Yoon, Minseong Kim, } \\
\text { Sungyeong } \quad \text { Yoon, Minjeong } \\
\text { Park(2007) }\end{array}$ \\
\hline Use attitude & An instrument that causes behavior using digital device & Norman \& Smith 1995 \\
\hline $\begin{array}{l}\text { Competency } \\
\text { level }\end{array}$ & $\begin{array}{l}\text { Consistent learning disposition, which is a benevolent or } \\
\text { unfriendly feeling or an emotional response to an action }\end{array}$ & Davis(1989) Adams \& Todd(1992) \\
\hline $\begin{array}{l}\text { Use } \\
\text { performance }\end{array}$ & $\begin{array}{l}\text { Achievements achieved by using digital devices. The result } \\
\text { obtained or done after doing something. }\end{array}$ & $\begin{array}{l}\text { Wolseok Kang, Myungsook Kim, } \\
\text { Jaewook Ko(2013) }\end{array}$ \\
\hline
\end{tabular}


The research model and the hypotheses are set as follows to understand the phenomenon of technology and information acceptance of the vulnerable groups. The impact level, motivation for use, attitudes toward use, and use performance of the vulnerable groups were investigated.

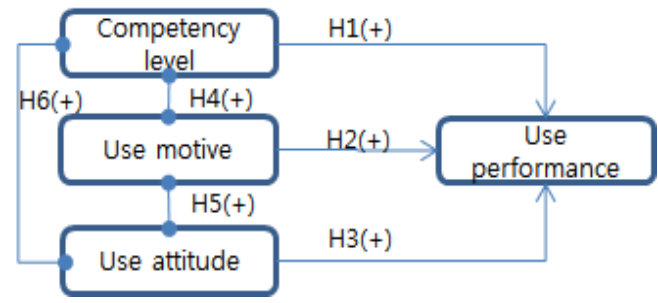

Figure 1. Research hypothesis model

H1: There is a positive correlation between competency level and use performance.

$\mathrm{H} 2$ : There is a positive correlation between use motive and use performance.

H3: There is a positive correlation between use attitude and use performance.

$\mathrm{H} 4$ : There is a positive correlation between competence level and use motive

H5: There is a positive correlation between use attitude and use motive

H6: There is a positive correlation between use attitude and competence level.

\subsection{Survey Design and Analysis Method}

The population group was classified into general public and vulnerable groups of information acceptance, and the vulnerable groups of information sets up 4 groups: disabled, low income, elderly, and farmers \& fishermen. The following are the classification criteria for each population group.

Table 2. Population classification criteria

\begin{tabular}{lll}
\hline Group & Contents \\
\hline General public & At the time of the survey, Koreans aged 17 years or older residing in households \\
\hline & $\begin{array}{l}\text { At the time of the survey, the Korean disabled persons aged } 7 \text { to } 69 \text { who are registered } \\
\text { by the Welfare for the Disabled Act (Delayed, brain lesion, hearing / language, visually } \\
\text { impaired) }\end{array}$ \\
\cline { 2 - 3 } Vulnerable & $\begin{array}{l}\text { At the time of the survey from 7 to 74 years old Basic Livelihood Security Recipient of } \\
\text { Korea registered by the National Basic Livelihood Security Act }\end{array}$ \\
\cline { 2 - 3 } & $\begin{array}{l}\text { At the time of the survey, more than 55-year-old Koreans who reside in Korean } \\
\text { households }\end{array}$ \\
\cline { 2 - 3 } $\begin{array}{l}\text { Farmer } \\
\text { Fishermen }\end{array}$ & $\begin{array}{l}\text { \& At the time of the survey, farmers and fishermen aged 15 or over who live in Korea's } \\
\text { farm households and fisherman's house }\end{array}$ \\
\hline
\end{tabular}

The survey was conducted online and by telephone from December 1, 2017 through December 20. The statistical program used for the analysis was IBM SPSS 28.0, which was used for descriptive statistics and T-test. In addition, factor analysis and reliability analysis were conducted to investigate whether the items investigated in the questionnaire properly explain each factor. The questionnaire was composed of 5 items of use motive, 6 items of use attitude, 7 items of competency level, and 7 items of use performance. 
Table 3. Contents of the questionnaire

\begin{tabular}{ll}
\hline Division & Number of questions \\
\hline Use motive & 5 \\
\hline Use attitude & 6 \\
\hline Competency level & 7 \\
\hline Use performance & 7 \\
\hline Total questions & 25 \\
\hline
\end{tabular}

\section{Analysis and Findings}

\subsection{Demographic Characteristics}

By the end of 2017, the sample group sampled 7,000 ordinary citizens and 8,900 vulnerable people nationwide according to their sex and age distribution. Demographic characteristics of the respondents are shown in the following table. The sex distribution of men and women was about $50 \%$, and the distribution of age was distributed from $14 \%$ to $20 \%$ of the general population. In the case of the vulnerable classes, it consisted of $50 \mathrm{~s}(26.5 \%)$ and $60 \mathrm{~s}$ $(56.05 \%$ ). In terms of educational standards, $44.2 \%$ (general public) and $40.1 \%$ (vulnerable class) participated in high school graduates, and $89.4 \%$ (general citizens) and $83.0 \%$ (vulnerable classes) In terms of in-come, $43.3 \%$ (ordinary people) was over 4 million won, and 32.4\% (vulnerable people) was 100-199 thousand won.

Table 4. Demographic characteristics of the sample population

\begin{tabular}{|c|c|c|c|c|c|}
\hline \multirow[b]{2}{*}{ Division } & \multirow[b]{2}{*}{ Category } & \multicolumn{2}{|c|}{ General public } & \multicolumn{2}{|c|}{ vulnerable group } \\
\hline & & $\begin{array}{l}\text { Number } \\
\text { cases }\end{array}$ & ${ }^{\text {of }}$ Ratio (\%) & $\begin{array}{l}\text { Number of } \\
\text { cases }\end{array}$ & Ratio (\%) \\
\hline \multirow{2}{*}{ Sex } & male & 3,492 & 49.9 & 4,512 & 50.7 \\
\hline & female & 3,508 & 50.1 & 4,388 & 49.3 \\
\hline \multirow{6}{*}{ Age } & Under 19 & 960 & 14.2 & 552 & 6.2 \\
\hline & 20 's & 948 & 14.0 & 231 & 2.6 \\
\hline & $30 \mathrm{~s}$ & 985 & 15.5 & 231 & 2.6 \\
\hline & $40 \mathrm{~s}$ & 1,055 & 18.1 & 543 & 6.1 \\
\hline & $50 \mathrm{~s}$ & 1,422 & 17.4 & 2,359 & 26.5 \\
\hline & More than 60 & 1,630 & 20.9 & 4,984 & 56.0 \\
\hline \multirow{4}{*}{$\begin{array}{l}\text { Educational } \\
\text { background }\end{array}$} & Under elementary school & 1,049 & 12.8 & 2,350 & 26.4 \\
\hline & Primary school graduate & 1,056 & 14.2 & 2,376 & 26.7 \\
\hline & High school graduate & 2,987 & 44.2 & 3,569 & 40.1 \\
\hline & College or higher & 1,907 & 28.7 & 605 & 6.8 \\
\hline \multirow{5}{*}{ Jobs } & Agriculture / Forestry / Fishing & 174 & 1.8 & 1,371 & 15.4 \\
\hline & Service / Sales & 2,042 & 29.6 & 1,682 & 18.9 \\
\hline & Production related & 771 & 10.5 & 1,353 & 15.2 \\
\hline & Professional Management / Office & 1,103 & 17.1 & 320 & 3.6 \\
\hline & housewife & 1,137 & 16.6 & 1,896 & 21.3 \\
\hline
\end{tabular}




\begin{tabular}{|c|c|c|c|c|c|}
\hline & student & 1,288 & 18.9 & 543 & 6.1 \\
\hline & Unemployed / Other & 485 & 5.5 & 1,735 & 19.6 \\
\hline \multirow{2}{*}{$\begin{array}{l}\text { By residence } \\
\text { size }\end{array}$} & City area & 6,163 & 89.4 & 7,387 & 83.0 \\
\hline & County Area & 837 & 10.6 & 1,513 & 17.0 \\
\hline \multirow{6}{*}{$\begin{array}{l}\text { Monthly } \\
\text { household } \\
\text { income }\end{array}$} & Less than 1 million won & 353 & 3.9 & 1,958 & 22.0 \\
\hline & 1 million to 1.99 million won & 801 & 9.6 & 2,884 & 32.4 \\
\hline & 2 million won to 2.99 million won & 1,222 & 16.0 & 1,762 & 19.8 \\
\hline & 3 million won to 3.99 million won & 1,916 & 26.9 & 1,228 & 13.8 \\
\hline & Over 4 million won & 2,688 & 43.3 & 1,059 & 11.9 \\
\hline & No answer & 20 & 0.4 & 9 & 0.1 \\
\hline \multicolumn{2}{|l|}{ Total } & 7,000 & 100 & 8,900 & 100 \\
\hline
\end{tabular}

\subsection{Technical Characteristics and Reliability Analysis by Factor}

In the case of the general public $(\mathrm{N}=7,000)$, the use motive, use attitude, and use performance were the highest with 3.04. This means that the ethnicity is higher in the use of information after acquiring information. Therefore, it is possible to be more active in accepting information because it is highly satisfied with the use performance result after experiencing information acceptance. The results of analysis according to gender, use motive, use attitude, and use performance were higher in males than females. According to the educational background, if people have high academic standards the correlation scores high. The scores of professional management and office workers were high by jobs and Students showed high scores for each factor. According to household income, the higher the income, the higher the use motive, the use attitude, and the use performance.

In the case of male, economic activity is higher than that of female, so there is more opportunity for information acceptance, and 20-30 aged is more active in accepting technology and information. It was also found that higher income earned more income through job or information acceptance, which is closely related to information acceptance.

Table 5. Demographic statistics by factors: general public

\begin{tabular}{|c|c|c|c|c|c|c|c|c|}
\hline \multirow[t]{2}{*}{ Division } & & \multicolumn{2}{|c|}{$\begin{array}{l}\text { Competency } \\
\text { level }\end{array}$} & \multicolumn{2}{|c|}{ Use motive } & \multirow{2}{*}{$\begin{array}{l}\text { Use attitude } \\
\text { Avg } \mathbf{t} / \mathbf{F}\end{array}$} & \multicolumn{2}{|c|}{ Use performance } \\
\hline & & Avg & $t / F$ & Avg & $t / F$ & & Avg & $\mathbf{t} / \mathbf{F}$ \\
\hline entirety & & 2.71 & & 2.68 & & 2.77 & 3.04 & \\
\hline \multirow{2}{*}{ Sex } & male & 2.86 & & 2.74 & & 2.81 & 3.06 & \\
\hline & female & 2.55 & $186.573 *$ & 2.62 & $61.812 *$ & $\overline{2.72} 38.185^{*}$ & 3.02 & \\
\hline \multirow{6}{*}{ Age } & Under 19 & 3.17 & & 3.05 & & 3 & 3.16 & \\
\hline & 20 's & 3.52 & & 3.06 & & 3.06 & 3.26 & \\
\hline & $30 \mathrm{~s}$ & 3.37 & & 2.92 & & $\overline{2.92}$ & 3.15 & \\
\hline & $40 \mathrm{~s}$ & 3.00 & & 2.79 & & 2.76 & 3.08 & \\
\hline & $\overline{50 \mathrm{~s}}$ & 2.46 & & 2.61 & 553.385 & $\overline{2.56}_{266.895}$ & 2.89 & \\
\hline & More than 60 & 1.58 & 1531.808 & 2.08 & $*$ & $2.37 *$ & 2.73 & \\
\hline Educational & Under elementary school & 1.95 & $512.974 *$ & 2.27 & 179.138 & $2.745 .693^{*}$ & 2.93 & $53.292 *$ \\
\hline
\end{tabular}




\begin{tabular}{|c|c|c|c|c|c|c|c|c|c|}
\hline \multirow[t]{3}{*}{ background } & Primary school graduate & 2.29 & & 2.52 & $*$ & 2.64 & & 2.94 & \\
\hline & High school graduate & 2.72 & & 2.74 & & 2.72 & & 3.01 & \\
\hline & College or higher & 3.33 & & 2.9 & & 2.91 & & 3.17 & \\
\hline \multirow{7}{*}{ Jobs } & Agriculture / Forestry / Fishing & 1.76 & & 2.08 & & 2.3 & & 2.72 & \multirow{7}{*}{$76.505^{*}$} \\
\hline & Service / Sales & 2.71 & & 2.72 & & 2.71 & & 3.01 & \\
\hline & Production related & 2.37 & & 2.5 & & 2.53 & & 2.86 & \\
\hline & Professional Management / Office & 3.36 & & 2.92 & & 2.94 & & 3.17 & \\
\hline & housewife & 2.13 & & 2.39 & & 2.58 & & 2.93 & \\
\hline & student & 3.28 & & 3.07 & 253.691 & 3.03 & 133.111 & 3.20 & \\
\hline & Unemployed / Other & 1.87 & $447.596^{*}$ & 2.14 & $*$ & $2.54 *$ & & 2.86 & \\
\hline \multirow{6}{*}{$\begin{array}{l}\text { Monthly } \\
\text { household } \\
\text { income }\end{array}$} & Less than 1 million won & 1.35 & & 1.73 & & 2.26 & & 2.59 & \multirow{6}{*}{$-87.28 * *$} \\
\hline & 1 million to 1.99 million won & 1.76 & & 2.16 & & $\overline{2.35}$ & & 2.74 & \\
\hline & 2 million won to 2.99 million won & 2.58 & & 2.66 & & 2.65 & & 2.94 & \\
\hline & 3 million won to 3.99 million won & 2.93 & & 2.78 & & 2.8 & & 3.06 & \\
\hline & Over 4 million won & 3.07 & & 2.89 & 365.333 & 2.89 & 108.473 & 3.14 & \\
\hline & No answer & 3.08 & $522.795^{*}$ & 2.96 & * & $2.93 *$ & * & 3.12 & \\
\hline
\end{tabular}

In the case of the vulnerable class $(\mathrm{N}=8,900)$, the analysis of the use motive, the use attitude, and the use performance showed that the average of the use performance in the whole sample was 2.81 , Coefficient values were higher in the lower age group than in the higher age groups.

By the education background, average was higher than college graduates of higher education, and job level was the highest in professional management / office worker at the level of competence as the general public. According to household income, high-income earners were higher the use motive, the use attitude, and the use performance. In the case of the vulnerable classes, males values were higher than females one, and higher education and high income were highly related to information acceptance, showing similar phenomena to general people.

Table 6. Demographic statistics by factors: vulnerable group

\begin{tabular}{|c|c|c|c|c|c|c|c|c|c|}
\hline \multirow{2}{*}{ Division } & & \multicolumn{2}{|c|}{ Competency level } & \multicolumn{2}{|c|}{ Use motive } & \multicolumn{2}{|c|}{ Use attitude } & \multicolumn{2}{|c|}{ Use performance } \\
\hline & & Avg & $\mathbf{t} / \mathbf{F}$ & Avg & $\mathbf{t} / \mathbf{F}$ & Avg & $\mathbf{t} / \mathbf{F}$ & Avg & $t / F$ \\
\hline entirety & & 1.95 & & 2.32 & & 2.5 & & 2.81 & \\
\hline \multirow{2}{*}{ Sex } & male & 2.10 & \multirow{2}{*}{$-314.204 *$} & 2.42 & \multirow{2}{*}{$-164.056^{*}$} & 2.54 & \multirow{2}{*}{$-33.496^{*}$} & 2.83 & \multirow{2}{*}{$-16.507 *$} \\
\hline & female & 1.78 & & 2.22 & & 2.45 & & 2.78 & \\
\hline \multirow{6}{*}{ Age } & Under 19 & 2.95 & \multirow{6}{*}{$-894.175 *$} & 2.95 & \multirow{6}{*}{$-361.017 *$} & 2.88 & \multirow{6}{*}{$-120.061^{*}$} & 3.04 & \multirow{6}{*}{$-65.319 *$} \\
\hline & 20 's & 3.26 & & 3.02 & & 2.94 & & 3.13 & \\
\hline & $30 \mathrm{~s}$ & 2.96 & & 2.85 & & 2.76 & & 3.01 & \\
\hline & $\overline{40 s}$ & 2.56 & & 2.66 & & 2.64 & & 2.90 & \\
\hline & $50 \mathrm{~s}$ & 2.20 & & 2.52 & & 2.49 & & 2.81 & \\
\hline & More than 60 & 1.54 & & 2.07 & & 2.34 & & 2.70 & \\
\hline Educational & Under & $y 1.43$ & $888.51^{*}$ & 1.91 & $460.769 *$ & 2.36 & $77.478^{*}$ & 2.64 & $74.338 *$ \\
\hline
\end{tabular}




\begin{tabular}{|c|c|c|c|c|c|c|c|c|}
\hline \multirow[t]{4}{*}{ background } & \multicolumn{8}{|l|}{ school } \\
\hline & $\begin{array}{l}\text { Primary } \\
\text { graduate }\end{array} \quad$ school $_{1.77}$ & & 2.28 & & 2.38 & & 2.74 & \\
\hline & High school graduate 2.23 & & 2.55 & & 2.54 & & 2.84 & \\
\hline & College or higher 2.94 & & 2.74 & & 2.77 & & 3.04 & \\
\hline \multirow{7}{*}{ Jobs } & $\begin{array}{ll}\text { Agriculture } & / \\
\text { Forestry / Fishing } & 1.85\end{array}$ & \multirow{7}{*}{$353.962 *$} & 2.15 & \multirow{7}{*}{$141.256^{*}$} & 2.43 & \multirow{7}{*}{$63.759 *$} & 2.75 & \multirow{7}{*}{$32.663^{*}$} \\
\hline & $\begin{array}{ll}\text { Service / Sales } \quad 2.11\end{array}$ & & 2.49 & & 2.53 & & 2.85 & \\
\hline & Production related 1.93 & & 2.38 & & 2.41 & & 2.74 & \\
\hline & $\begin{array}{l}\text { Professional } \\
\text { Management / Office } 3.05\end{array}$ & & 2.74 & & 2.77 & & 2.99 & \\
\hline & housewife & & 2.14 & & 2.38 & & 2.75 & \\
\hline & student & & 2.94 & & 2.90 & & 3.05 & \\
\hline & Unemployed / Other 1.70 & & 2.18 & & 2.44 & & 2.74 & \\
\hline \multirow{6}{*}{$\begin{array}{l}\text { Monthly } \\
\text { household } \\
\text { income }\end{array}$} & $\begin{array}{l}\text { Less than } 1 \text { million } 1.57 \\
\text { won }\end{array}$ & \multirow{6}{*}{$172.738 *$} & 2.04 & \multirow{6}{*}{$120.317 *$} & 2.40 & \multirow{6}{*}{$21.58^{*}$} & 2.70 & \multirow{6}{*}{$23.832 *$} \\
\hline & $\begin{array}{l}1 \text { million to } 1.99 \\
\text { million won }\end{array}$ & & 2.27 & & 2.45 & & 2.76 & \\
\hline & $\begin{array}{l}2 \text { million won to } \\
2.99 \text { million won }\end{array}$ & & 2.44 & & 2.48 & & 2.80 & \\
\hline & $\begin{array}{l}3 \text { million won to } \\
3.99 \text { million won }\end{array}$ & & 2.50 & & 2.55 & & 2.88 & \\
\hline & Over 4 million won 2.37 & & 2.61 & & 2.65 & & 2.93 & \\
\hline & No answer & & 3.10 & & 2.94 & & 2.90 & \\
\hline
\end{tabular}

As a result of the reliability analysis of each item constituting the factor variable, Chronbach's $\alpha$ was 0.8 or more, and it was found that the reliability of the scale composition was high. Therefore, the evaluation of information acceptance of not only the general public but also the vulnerable groups was found appropriate using each factor.

Table 7. Technical statistics by factors

\begin{tabular}{llllll}
\hline Division & & Number of Question & Average & \multicolumn{2}{l}{ Standard derivations Chronbach's $\boldsymbol{\alpha}$} \\
\hline \multirow{4}{*}{$\begin{array}{l}\text { General } \\
\text { public }\end{array}$} & Competency level & 14 & 2.71 & 0.98 & 0.979 \\
\cline { 2 - 6 } & Use motive & 5 & 2.68 & 0.68 & 0.865 \\
\cline { 2 - 6 } & Use attitude & 6 & 2.77 & 0.57 & 0.822 \\
\cline { 2 - 6 } & Use performance & 7 & 3.04 & 0.49 & 0.803 \\
\cline { 2 - 6 } & Total questions & 32 & 1.95 & 0.937 & 0.978 \\
\hline \multirow{3}{*}{$\begin{array}{l}\text { Vulnerable } \\
\text { Group }\end{array}$} & Competency level & 14 & 2.32 & 0.767 & 0.900 \\
\cline { 2 - 6 } & Use motive & 5 & 2.50 & 0.61 & 0.851 \\
\cline { 2 - 6 } & Use attitude & 6 & 2.81 & 0.55 & 0.835 \\
\hline
\end{tabular}




\subsection{Correlation Analysis Result by Research Factor}

\subsubsection{General Public}

As a result of correlation analysis between competency level and use motive, use attitude, and use performance, correlation coefficient for each angle was $.473 \sim .682$ level. The correlation coefficient between use attitude and use performance was high, 0.682. On the other hand, the correlation coefficient between competency level and use performance was .473 , indicating that the correlation was relatively weak compared to other factors.

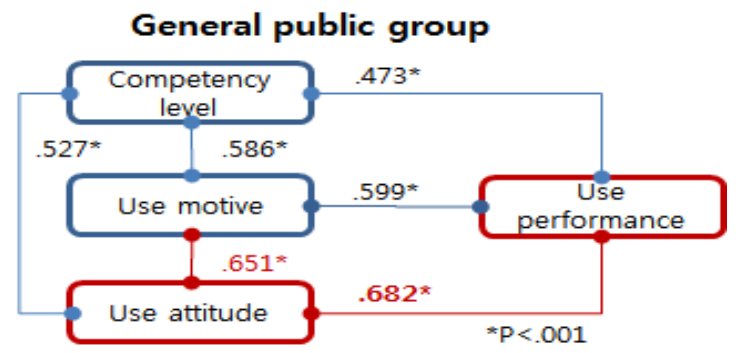

Figure 2. Correlation analysis of research model $(* \mathrm{p}<0.05)$

As a result of this study, the correlation coefficient of .500 or more was selected as the adoption criterion, and it is evaluated that each factor has a strong correlation with each other except for the relationship between competency level and use performance. In particular, the use attitude and use performance were found to have the strongest positive correlation.

Table 8. Correlation analysis of information acceptance factors for the general public (* at the $\mathrm{P}<0.05$ level)

\begin{tabular}{lll}
\hline Division & Pearson Correlation coefficient & Result \\
\hline Competency level $\leftrightarrow$ Use performance & $.473^{*}$ & Reject \\
\hline Competency level $\leftrightarrow$ Use motive & $.586^{*}$ & Accept \\
\hline Competency level $\leftrightarrow$ Use attitude & $.527^{*}$ & Accept \\
\hline Use motive $\leftrightarrow$ Use performance & $.599^{*}$ & Accept \\
\hline Use motive $\leftrightarrow$ Use attitude & $.651^{*}$ & Accept \\
\hline Use attitude $\leftrightarrow$ Use performance &. $\mathbf{6 8 2}^{*}$ & Accept \\
\hline
\end{tabular}

\subsubsection{Vulnerable Group}

As a result of analyzing the group of vulnerable classes, it was found that the use motive, the use attitude, and the use performance have a relatively high correlation of .635 or more.

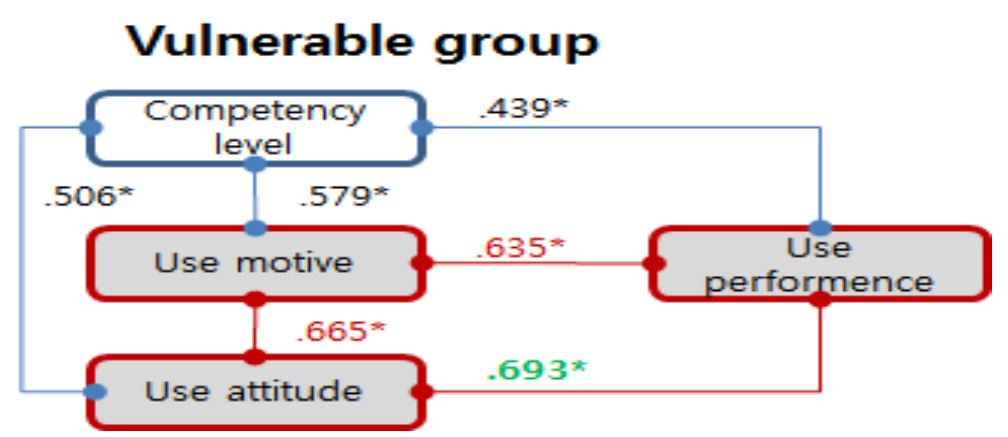

Figure 3. Correlation analysis of research model 
The results of this study showed that adoption was conducted when the correlation was over .500 , and that the competence level and use performance was lowered to .439. The correlation between the use performance of the vulnerable class and the use attitude was .693, which was higher than that of general public group, .682. Therefore, in the case of the vulnerable group, the information reception environment should be created through various programs that can affect the attitude of using.

Table 9. Correlation analysis of information acceptance factors for the vulnerable group ${ }^{*}$ at the $\mathrm{P}<0.05$ level)

\begin{tabular}{lll}
\hline Division & Pearson Correlation coefficient & Results \\
\hline Competency level $\leftrightarrow$ Use performance & $.439^{*}$ & Reject \\
\hline Competency level $\leftrightarrow$ Use motive & $.579^{*}$ & Accept \\
\hline Competency level $\leftrightarrow$ Use attitude & $.506^{*}$ & Accept \\
\hline Use motive $\leftrightarrow$ Use performance & $.635^{*}$ & Accept \\
\hline Use motive $\leftrightarrow$ Use attitude & $.665^{*}$ & Accept \\
\hline Use attitude $\leftrightarrow$ Use performance &. $\mathbf{6 9 3}^{*}$ & Accept \\
\hline
\end{tabular}

The Pearson correlation coefficient of the use attitude and use performance was the highest among the vulnerable groups. In the case of low incomes, the correlation between use motive and competence level is also investigated. This means that the ability to use digital devices is important for sustainable economic activities in the future, and it is necessary to manage life by using digital devices and always actively learn new technologies (Dong \& Qiu 2018).

In addition, it means that the use of digital devices is high so that students can keep online in the best condition, such as checking the Internet access, security of digital devices, and enjoying online education as lifelong learners.

\section{[Disabled group]}

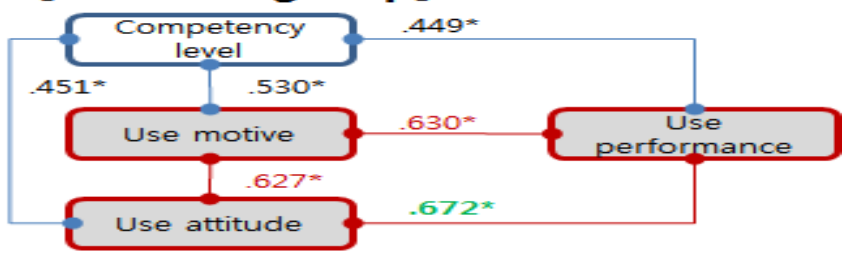

[Low Income group]

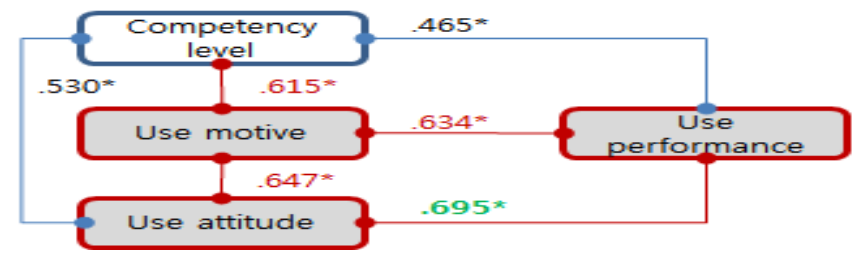

Figure 4. Factors correlation of disabled and low-income group

In the case of farmers \& fishermen and elderly people, it was also found that the use attitude and use performance showed the highest correlation. In addition, the relationship between competency level and use performance was relatively lower. As mentioned above, information use attitudes and information use performance have a close relationship with each other, and there is a close relationship between information use attitude and use motive, followed by low-income households (.695), farmers \& fishermen (.688), elderly group (.674). Therefore, introduction of various programs that can increase the use attitude and use performance should lead the vulnerable groups to use the information and to satisfy the users. 
[Farmer \& fishermen group]

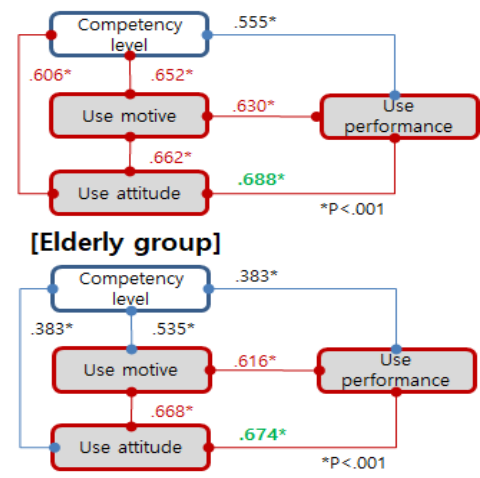

Figure 5. Factors correlation of farmers \& fishermen and elderly people group

Ultimately, it can be seen that the improvement of the government acceptance of the vulnerable groups can reduce the digital information divide.

\section{Conclusion}

The statistical analysis of each factor was classified into general public and vulnerable groups. According to the analysis of the general public sample, the information use performance was higher than other factors. This suggests that if the information use performance is high then people have a tendency of satisfying with the information use acceptance. In the case of economic activity, males are higher than females, so men has more opportunity for information acceptance, and 20-30 age groups tend to be more aggressive in accepting technology and information than other age groups. This study suggests that there is a strong positive correlation between income and information acceptance. In this case, income was evaluated to be influenced directly or indirectly by information acceptance.

As a result of the analysis of the vulnerable classes, the score of the information acceptance factor was higher in males than in females, and in the case of higher education and higher income, each factor was highly investigated and showed a similar phenomenon to the general public group. However, as a result of the job analysis, the reason for the high level of the students is analyzed for reasons of low age. The correlation analysis results showed that the use attitude and use performance showed the strongest positive correlation with the general public (.682) and the vulnerable class (.693).

In the case of the general public, the correlations between competence level, use motives, use attitudes, and use performance were found to be positively correlated, with a correlation coefficient of $.473 \sim .682$.

In general public group, there was a strong positive correlation between factors, and the correlation coefficient between use attitude and use performance was highest at 0.682 .

On the other hand, the correlation coefficient between competency level and use performance was .473 , indicating that the correlation was relatively weak compared to other factors. In this study, adoption was made when the correlation value was .500 or more.

As a result of analyzing the whole of the vulnerable classes, the use attitude and use performance result is higher than the general public group by .693. The results were lowered to .439 for competence level and use performance, and other factors were highly correlated.

The detailed classification of vulnerable groups shows that information use attitudes and information use performance have a close relationship with each other, and there is a close relationship between information use attitudes (.695), farmers \& fishermen (.688), elderly people (.674) respectively. In conclusion, as the use attitude toward information increases, the information acceptance use performance is higher.

Table 10. Correlation analysis of information acceptance factors for the Vulnerable group $(*$ at the $\mathrm{P}<0.05$ level)

\begin{tabular}{llll}
\hline \multirow{2}{*}{ Division } & General Public & Vulnerable Group \\
& Pearson & CorrelationPearson & Correlation
\end{tabular}




\begin{tabular}{llll}
\hline & coefficient & coefficient & \\
\hline Competency level $\leftrightarrow$ Use performance & $.473^{*}$ & $.439^{*}$ & Reject \\
\hline Competency level $\leftrightarrow$ Use motive & $.586^{*}$ & $.579^{*}$ & Accept \\
\hline Competency level $\leftrightarrow$ Use attitude & $.527^{*}$ & $.506^{*}$ & Accept \\
\hline Use motive $\leftrightarrow$ Use performance & $.599^{*}$ & $.635^{*}$ & Accept \\
\hline Use motive $\leftrightarrow$ Use attitude & $.651^{*}$ & $.665^{*}$ & Accept \\
\hline Use attitude $\leftrightarrow$ Use performance & $\mathbf{. 6 8 2}$ & $\mathbf{. 6 9 3}$ & Accept \\
\hline P value(criteria) & $\mathbf{P}<\mathbf{0 . 0 5}$ & $\mathbf{P}<\mathbf{0 . 0 1}$ & \\
\hline
\end{tabular}

The implication of the conclusion is that a variety of programs should be introduced to increase the attitude and performance of users, so that vulnerable groups should be encouraged to use attitude and use performance. Ultimately, it was found that the improvement of information acceptance of vulnerable groups could reduce digital information gap. In order to expand the acceptance of information by vulnerable groups, various programs that can change the use attitude as well as use performance of information should be discovered and provided. Therefore, the implications of the above results are that, in order to expand information acceptance to vulnerable groups in the country Korea, the digital utilization capacity is also important, but the policy should be led to positively change the use attitude by providing motivation to use information. For example, it is necessary to suggest ways to expand opportunities for experiencing various educational and information devices to facilitate information acceptance.

The expected effect of this study is that it provides the supporting data for the policy making to expand the information receiving capacity of the vulnerable classes. This study has limitations in securing the broad wide content of in-depth questionnaires. In addition, it is necessary to analyze various factors in addition to factors selected as environmental factors of information acceptance. Future directions should be based on various information acceptance factors for the vulnerable groups

\section{Acknowledgement}

This paper was quoted in part of the in-depth report which was supported by Korea National Information Agency.

\section{References}

Adams, D. A., Nelson, R., \& Todd, P. A. (1992). Perceived usefullness, easy of use, and useage of information technology: a replication. MIS Quartely, 16(2), 227-247. https://doi.org/10.2307/249577

Ali, A., \& Haseeb, M. (2019). Radio frequency identification (RFID) technology as a strategic tool towards higher performance of supply chain operations in textile and apparel industry of Malaysia. Uncertain Supply Chain Management, 7(2), 215-226. https://doi.org/10.5267/j.uscm.2018.10.004

Cases, C. A. (2010). Factors That Determine Attitudes Toward the Use Technology to Plan for Retirement: An Empirical Analysis, p. 4. St Thomas Aquinas College, Sparkill, NY.

Choi, H. S., \& Park, J. W. (2009). Effects Characteristics of Mobile Information Service on Satisfaction and Reuse Intention. The Journal of the Korea Contents Association. https://doi.org/10.5392/JKCA.2009.9.9.411

Choi, Y., \& Choi, H.-S. (2011). Effects Tourism Storytelling on Tourist's Attitude: Mt. Hanla on Jeju Island. The Journal of the Korea Contents Association. https://doi.org/10.5392/JKCA.2011.11.12.442

Davis, F. (1989). Perceived usefulness, perceived ease of use, and user acceptance of information technology. MIS Quarterly, 13(3), 319-40. https://doi.org/10.2307/249008

Dincer, N., \& Kilinç, Z. (2018). The Analysis of Stress Levels of the Female Wrestlers Studying in Higher Education (A Case of Batman Province). Asian Journal of Education and Training, 4(3), 156-160.

Dong, T., \& Qiu, L. (2018). Research on Self-Mentions and Author Identity in Academic English Writing. International Journal of English Language and Literature Studies, 7(4), 115-121.

Dulcic, Z., \& Pavlic, D. (2012, October). Evaluating the Intended Use of Decision Support System (DSS) by Applying Technology Acceptance Model (TAM) in Business Organizations in Croatia. Procedia - Social and Behavioral Sciences, 58, 1565-1575. https://doi.org/10.1016/j.sbspro.2012.09.1143

Essien, J. M., Gbeghe, B. D., Kpunee, H. N., \& Piabari, N. (2016). E-Marketing Products and Financial Inclusion in Nigeria. International Journal of Economics, Business and Management Studies, 3(1), 47-54. 
Etale, L. M., Bingilar, P. F., \& Ifurueze, M. S. (2016). Market share and profitability relationship: A study of the banking sector in Nigeria. International Journal of Business, Economics and Management, 3(8), 103-112.

Faisal, F., Tursoy, T., \& Resatoglu, N. G. (2017). Is Export-Led Growth Hypothesis Exist in Saudi Arabia? Evidence from an ARDL Bounds Testing Approach. Asian Journal of Economic Modelling, 5(1), 110-117.

Ferguson, D. A., \& Perse. E. M. (2001). Enhanced television viewing with digital video recorders: Audience satisfaction in an asynchronous television environment. AEJMC Conference Papers.

Gabriel, P. (2017). Towards the Geopolitical-Economics of Conflict Over Resources: The Gate Valve Theory. Energy Economics Letters, 4(1), 1-8. https://doi.org/10.18488/journal.82.2017.41.1.8

Ham, Y., An, J. M., \& Lee, S. J. (2006). The Extended TAM(Technology Acceptance Model) and Groupware Usage Intention. Journal of Information Technology Applications \& Management.

Handa, R. (2018). Does Corporate Governance Affect Financial Performance: A Study of Select Indian Banks. Asian Economic and Financial Review, 8(4), 478-486.

Ibrahim, H. B. H., Johnson, S., Gilligan, P., \& Adu-Gyamfi, J. (2018). Critical Reflection on My PhD Research Experience. International Journal of Asian Social Science, 8(10), 856-867.

Jermsittiparsert, K. (2016). Culture of 'Elephant front legs-hind legs': A debate on the actuality of sexual politics in Thai society. The Social Sciences, 11(1), 20-28.

Kang, W. S., Kim, M. S., \& Ko, J. U. (2013). Effects of the Smartphone Information Use and Performance on Life Satisfaction among the Elderly. Korea Gerontological Society.

Kim, J. (2015). A Study on Initial Characterization of Big Data Technology Acceptance - Moderating Role of Technology User \& Technology Utilizer. The Journal of the Korea Contents Association.

Min, Y. (2011). The Digital Divide among Internet Users: An Analysis of Digital Access, Literacy, and Participation. Journal of Communication Research.

Morris, M., \& Ogan, C. (1996). The internet as mass medium. Journal of Communication, 46(1), 39-48.

Myeni, S. L., \& Mvuyana, B. Y. (2018). Participatory Processes in Planning for Self-Help Housing Provision in South Africa: Policies and Challenges. International Journal of Public Policy and Administration Research, 5(1), 24-36.

Norman, P., \& Smith, L. (1995). The theory planned behaviour and exercise : An investigation into the role of prior behaviour, behaviour intentions and attitude variability. European Journal of Social Psychology, 25(4), 403-415. https://doi.org/10.1002/ejsp.2420250405

Pai, F. Y., \& Huang, K. I. (2011). Applying the technology acceptance model to the introduction of healthcare information systems. Technological Forecasting and Social Change, 78(4), 650-660.

PPV (Pay Per View). (n.d.). Use. Korean Broadcasting Institute.

Sangakala, M., Ahmed, U., \& Pahi, M. H. (2016). Empirical investigating on the role of supervisor support, job clarity, employee training and performance appraisal in addressing job satisfaction of nurses. International Business Management, 10(23), 5481-5486.

Tyagi, S., \& Siddiqui, S. (2017). Yield Curve and Momentum Effects in Monthly US Equity Returns: Some Nonparametric Evidence. Asian Journal of Economics and Empirical Research, 4(2), 61-67. https://doi.org/10.20448/journal.501.2017.42.61.67

Yoo, S. J., Kim, H., Tang, H.-L. (2007). A Study on the Factors Affecting the Acceptance Intention for Mobile Ads. Information Systems Review.

Yoo, S.-J., Kim, H.-J., \& Tang, H.-L. (2007). A Study on the Factors Affecting the Acceptance Intention for Mobile Ads. Information Systems Review, 9(1), 1-21.

Youn, J., Kim, M., Youn, S., \& Park, M. (2007). The Essential Characteristics and Dimensions of Competence as Human Ability. The Korean Education Research Association. 